\title{
Perception of natural habitat changes of West African marine protected areas
}

\author{
Failler Pierre ${ }^{1}$, Touron-Gardic Gregoire ${ }^{1,{ }^{*}}$, Sadio Oumar ${ }^{2}$, Traore Marie-Suzanne ${ }^{3}$
}

1 Univ Portsmouth, Fac Econ \& Law, Ctr Blue Governance, Portsmouth P01 3DE, Hants, England.

2 Res Inst Dev IRD, UMR LEMAR 195 Marine Sci Lab MARin, Dakar 1386, Senegal.

${ }^{3}$ Marine Protected Areas Network West Africa RAMPAO, Sacred Heart 3, Dakar, Senegal.

* Corresponding author : Grégoire Touron-Gardic, email address : gregoire.touron-gardic@port.ac.uk ;

pierre.failler@port.ac.uk ; oumar.sadio@ird.fr ; secretariat@rampao.org

\begin{abstract}
:
The evolution of marine protected areas (MPAs) in West Africa is reviewed through a survey of managers' perception carried on between 2017 and 2018 for the establishment of the baseline of MPAs of the Network of Marine Protected Areas of West Africa (RAMPAO). Managers report that all natural habitats are subject to surface area losses. The most affected habitats were beaches, mudflats and estuarine channels, caused by erosion and rainfall deficit. Seagrasses, rocky bottoms and coral reefs also seem to be affected, but as they are not monitored and as the managers' knowledge is poor toward these habitats, changes are not properly recorded. Despite some damages, coastal forests seem to be the only natural habitat that see positive changes, mainly due to regular reforestation activities. Comparing managers' perception to scientific papers using satellite imagery shows that their judgement is similar for some habitats (beaches and forests), although there are some differences between their perception and scientific analyses about mangroves changes and even between scientific analyses themselves. However, managers' understanding of impacts coming from human activity and climate change is not strong enough. Consequently, these threats were impossible to quantify from this perception survey. Finally, there is a lack of GIS data within the MPAs.
\end{abstract}

\section{Highlights}

- Main natural habitats in west african MPAs are losing surface, according managers. The beach areas, mudflats and estuarine channels are the most exposed habitats. Only forests appear to be generally positive, due to reforestation activities. Seagrasses, rocky bottoms and coral reefs are barely monitored. Perceptions partly differ from satellite analyses, while located data are lacking.

Keywords : Environmental change, Marine Protected Areas (MPAs), Manager perception, Satellite images, Habitats changes 


\section{Introduction}

Various drivers of pressure, including a doubling of the population on average every 27 years (United Nations, 2017) and expanding inland salinity, increasingly threaten the ecology of West African coastlines (Cormier-Salem, Dieye and Sane, 2016; Cormier-Salem, 2017; IPBES, 2018). Despite their protected status, Marine Protected Areas (MPAs) face the same threats (Diop and Scheren, 2016). Yet, very few programs exist to monitor changes in natural habitat of the West African coastline, although international conventions and targets such as the Aichi Targets advocate that knowledge about biodiversity should be "improved, widely shared and transferred, and applied". None of these programs are dedicated to MPAs, despite the fact that some research has been conducted at site level (Vasconcelos et al., 2002; Gourmelon et al., 2006; Alban et al., 2011; Sakho et al., 2011; Ceesay et al., 2017). Further, only mangroves have been regularly monitored (Carney, Gillespie and Rosomoff, 2014; Cormier-Salem and Panfili, 2016; Temudo and Cabral, 2017; Duncan et al., 2018), while seagrass are only recently studied within the ResilienSEA project.

The objective of this article is to analyze changes in natural habitats of 28 MPAs adhering to the Network of Marine Protected Areas of West Africa (RAMPAO) as perceived by MPAs managers. The results are from a perception survey of MPA managers carried out between 2017 and 2018 as part of the realisation of the baseline of the MPAs in the network (Failler, Sadio and Touron-Gardic, 2018). MPA managers expressed a perceived evolution of habitats within their MPAs. In the absence of regular monitoring, such perception surveys are presented as a convincing alternative to study the changes affecting natural habitats (AlvarezBerastegui et al., 2014). These managers' perceptions have focused on the change of natural habitat surface areas, which can be considered as an indicator of change (He et al., 2014).

The paper consists of three parts. The first part focuses on the method used and describes data collection and analysis. The second part discusses the type of recurrent habitats in the RAMPAO MPAs, as well as their changes. The third part compares these changes with recent studies that used satellite imagery. This section also discusses the limits of perception surveys in the field of environmental monitoring. In addition, the level of conservation achievements by MPAs are discussed. The article concludes with the main points developed and suggests avenues for improvement.

\section{Method}

\subsection{Questionnaire}

As part of the baseline study of the RAMPAO MPAs conducted between June 2017 and May 2018, managers of all MPAs in the network were interviewed on their perceptions of the change of natural habitats. A questionnaire recorded manager's understanding of the state of health and the evolution of protected habitats, the pressures that affect their functioning and actions needed to be undertaken to ensure their sustainability (a copy of the questionnaire is presented in the Annex). In addition, managers were asked to provide information on the 
nature of the monitoring undertaken for each habitat. Following a "mail out" process, managers were re-contacted until they responded in a satisfactory way to the questionnaires. At the end, questionnaires for 28 MPAs were completed out of a total of 32 MPAs in the network at the time of the survey, representing an $87 \%$ response rate (the Cap Blanc satellite reserve in Mauritania, the Djoudj and Saloum Delta national parks in Senegal and the Orango national park in Guinea-Bissau did not return questionnaires). These MPAs are situated on the coasts, islands, estuaries, coastal lagoons and mangroves along six West African countries: Mauritania, Senegal, Gambia, Cabo Verde, Gambia, Guinea-Bissau and Guinea (see Figure 1). There are only five MPAs that are exclusively marine, and they are all found in Senegal: Saint-Louis, Kayar, Joal, Sangomar and Abéné. It is important to note that a larger number of MPAs are present in these countries (Failler et al., 2020), but they are not RAMPAO members. 


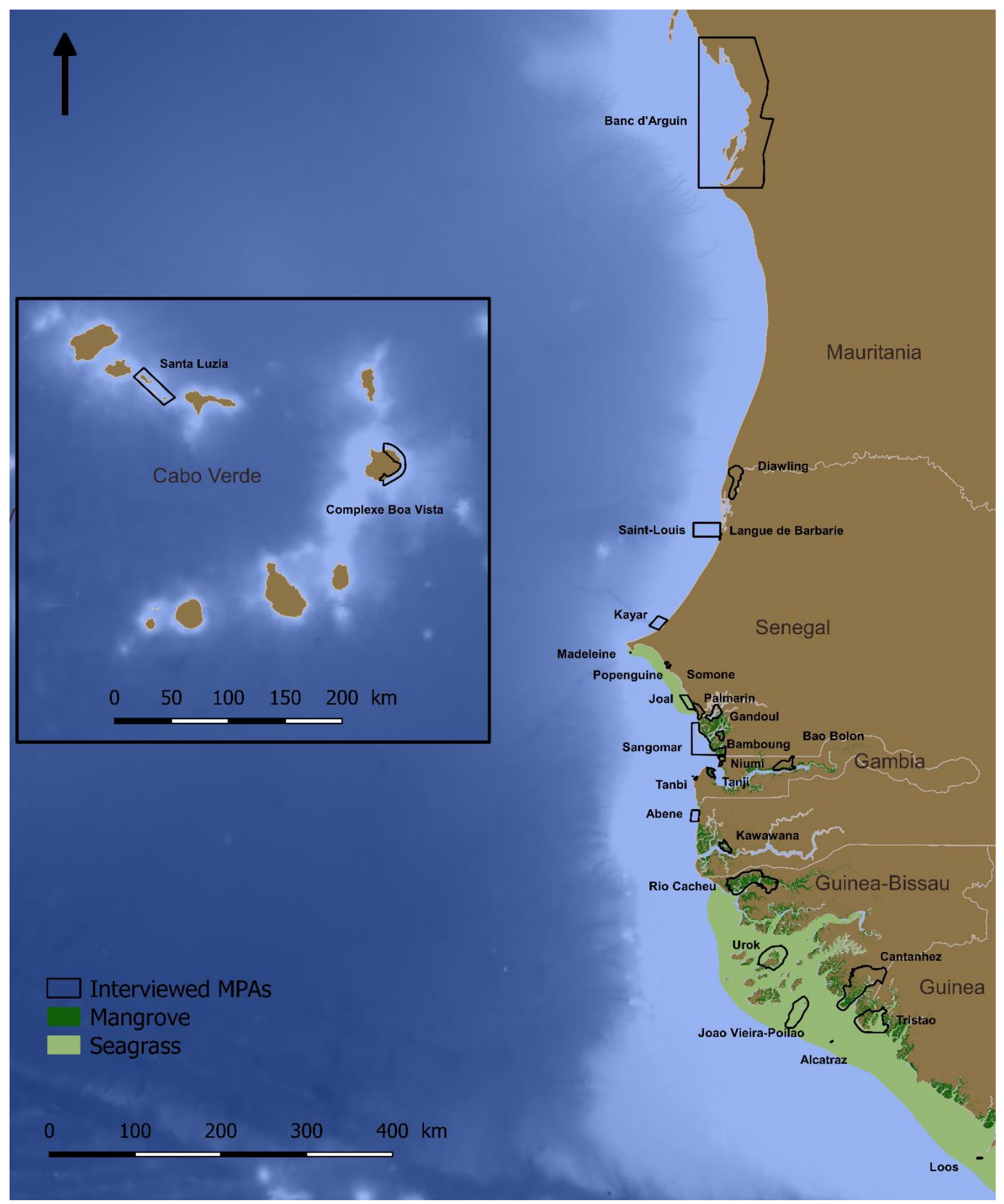

Figure 1 : Distribution of the MPAs surveyed during the reference state of MPAs in West Africa (20172018), bathymetry and global distribution of Seagrass and Mangrove in the area of investigation. Sources: Bathymetry: GEBCO 2019; Seagrass distribution: UNEP-WCMC 2018; Mangrove distribution: UNEPWCMC 2014.

The changes of the surface area and the health status of each habitat was informed according to the knowledge of the manager and was considered as an "expert statement". As far as possible, it was based on the available documents and reports detailing the monitoring undertaken. The manager also considered the information obtained from the user groups and from the management staff to answer the questionnaire. Managers are civil servants who stay in duty for several years before being assigned to another location. Staff employees typically 
work on protected area for most of their careers. Managers who were relatively new on the protected areas could rely on staff to provide a record on past events and therefore be able to provide a perception over the last 5 years. Managers were asked two simple questions:

- What kind of changes in natural habitats surface areas do you observe? Managers had to select their answer using the following scale: very high increase, high increase, moderate increase, no changes, moderate decrease, high decrease and very high increase. They had to answer separately for each habitat present within the MPA.

- What kind of changes in natural habitats health do you observe?

Following the same process as the first question.

The completion rate of the aspects relating to the evolution of the health status of the habitats was $40 \%$ against nearly $66 \%$ for those associated with surfaces. Managers were less willing to provide information on the level of degradation or improvement of the health status of natural habitats, but more willing to describe the changes in their surface area. Therefore, this article only accounts for the changes relating to the surface area of the different habitats and leaves aside the change in the health status of the protected areas.

\subsection{Satellite Imagery}

To validate the managers' statements about habitat degradation and science-based evidences, the information generated from the survey of MPA managers was compared to maps of the natural habitat changes along the West African coast using satellite imagery (providing the contour of the network's MPAs). These maps were based on work produced during the last 10 years by Andrieu (Andrieu, 2018), Balla Dieye (Balla Dieye et al., 2013), Carney (Carney, Gillespie and Rosomoff, 2014) and Conchedda (Conchedda, Durieux and Mayaux, 2008). Despite using different timelines, they globally overlap in time (see Table 1), which makes possible to compare them with each other as well as with the current perception survey.

\section{Results}

\subsection{Manager reported Changes in Habitat Surface Area}

Managers reported that beaches, mangroves and mudflats are the most represented habitats within the MPA network, followed by seagrasses and forests (see Figure 2). These littoral zone habitats demonstrate the coastal and estuarine character of the RAMPAO, as seen previously in the Figure 1. Conversely, coral reefs and rocky bottoms are the type of habitat that managers consider to be the least recurrent. Moreover, the monitoring of these submerged habitats, as well as seagrass beds, are the most poorly completed of all habitats in the MPAs surveyed (see Figure 2 and Figure 3, cases of "Presence without assessment"). On the other hand, beaches, mangroves, mudflats and forests have satisfying monitoring rates (more than $85 \%$ of managers are observing their evolutions in terms of surface areas), when estuarine channels have a $65 \%$ rate which could be easily improved. 


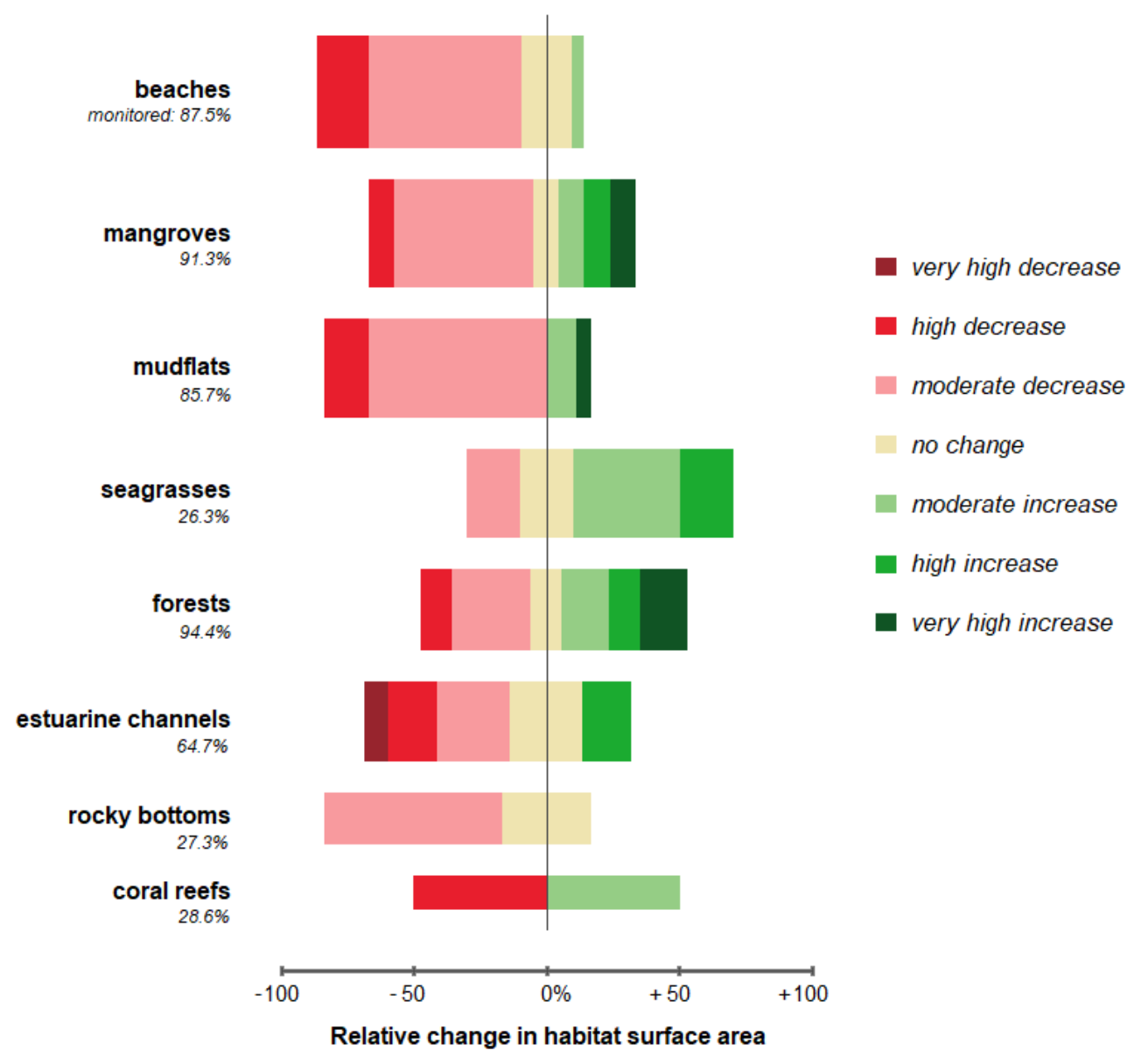

Figure 2: Evolution of habitat surface area in RAMPAO MPAs as perceived by MPA managers. The bar widths are proportional to their recurrence inside of the MPAs, with the first habitat (beaches) being the most recurrent $(n=24)$ and the last habitat (coral reef) being the least recurrent $(n=7)$ according to the managers. Under the habitat legend is written the percentage of monitoring for each type of habitat in the MPAs (which is not linked to the bars).

In the opinion of the managers, all habitats present in RAMPAO MPAs have been degraded over the past decade, although some have occasionally had positive evolutions (see Figure 2). Except for seagrasses and coral reefs whose monitoring is too weak to be counted, forests are thus, according to the managers, the only ecosystems that have evolved relatively positively in recent years. Beaches are the type of habitat that seem to suffer the biggest surface area losses, just before the mudflats. In addition, only few positive evolutions have been observed for both. Estuarine channels and mangroves come subsequently, enduring relatively large losses but also meeting some improvements in some cases. Fortunately, most of the recorded losses have a moderate level of severity, except for estuarine channels.

The changes in habitats surface area were heterogeneous among MPAs (see Figure 3). For example, with the exception of three MPAs (two of which are in Mauritania - Diawling and Banc d'Arguin), mudflat surface areas decreased. Globally, Diawling had positive evolutions in all his habitats. Having positive evolutions in terms of mangrove and forest surface areas, Cacheu seem also to be in a positive momentum. Four Senegalese MPAs also show positive evolutions in their mangrove areas: Langue de Barbarie, Abéné (but this site is nearly totally 
composed of marine sea), Palmarin and Somone. However, Langue de Barbarie and Somone seem to undergo threats in all other habitats. Furthermore, Iles de Loos, Gandoul and SaintLouis notice surface area decreases in all their natural environments (4 types of habitats or more).

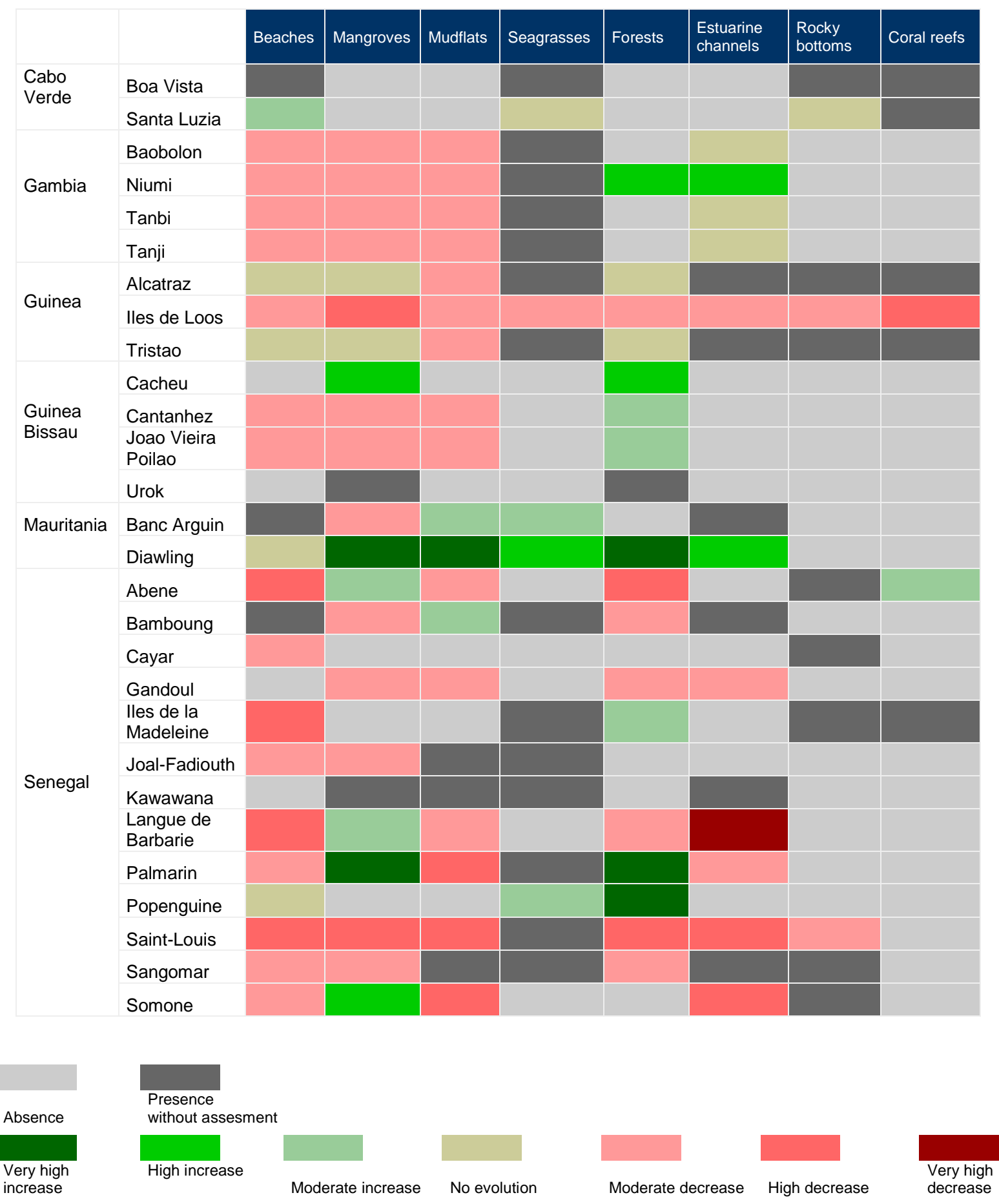

Figure 3 : Summary of changes in the natural habitats surface areas in RAMPAO MPAs

The only habitat recorded by MPA managers to have undergone very high decrease was estuarine channels in the Langue De Barbarie MPA because of human-made breach. Only one of the eight habitat types surveyed was reported to have had an overall positive growth across 
the MPAs. Forests showed a slight positive increase with increasing forested area in eight MPAs vs decreasing forested area in seven MPAs (with it being recorded in one MPA without assessment, with two being recorded as "no changes" and being absent in the remaining ten MPAs). The MPAs of Diawling, Palmarin, Popenguine, Cacheu and Niumi, recorded 'high' to 'very-high' increases in forested area. The second habitat to receive the most mentions of positive growth was mangroves (6 mentions). However, this growth varied across the MPAs, as losses were mentioned twice as often (13 mentions) and "no changes" were mentioned twice. Overall, except for these two environments, growth was only recorded ten other times for the six other habitats in all MPAs.

\subsection{Comparing Manager reported Changes with Satellite Imagery}

In order to verify the recurrence of actual trends in the MPAs, recent studies have been gathered and examined. Based on satellite images, they show the evolution of land use along the West African coast (Conchedda, Durieux and Mayaux, 2008; Balla Dieye et al., 2013; Carney, Gillespie and Rosomoff, 2014; Andrieu, 2018). By affixing the outline of the MPAs on these images, it is possible to compare the observations made by the managers with the conclusions resulting from these studies (See Table 1).

Table 1 : Summary of the evolution of the habitats in the different studies via satellite images and current perception of the managers

\begin{tabular}{|c|c|c|c|c|c|c|}
\hline & & $\begin{array}{l}\text { Managers' } \\
\text { perception in } \\
\text { the present } \\
\text { work }\end{array}$ & $\begin{array}{l}\text { Andrieu } \\
2018\end{array}$ & $\begin{array}{l}\text { Carney et } \\
\text { al. } 2014\end{array}$ & $\begin{array}{l}\text { Balla } \\
\text { Dieye et } \\
\text { al. } 2013\end{array}$ & $\begin{array}{l}\text { Conchedda } \\
\text { et al. } 2008\end{array}$ \\
\hline \multicolumn{2}{|c|}{ Study time scale } & 2018 & 1999-2015 & $1986-2010$ & 2001-2010 & 1986-2006 \\
\hline \multirow{3}{*}{ Mangroves } & $\begin{array}{l}\text { Saloum } \\
\text { delta }\end{array}$ & Increase & Increase & & Increase & \\
\hline & $\begin{array}{l}\text { Gambia } \\
\text { Estuary }\end{array}$ & Decrease & Increase & Decrease & & \\
\hline & $\begin{array}{l}\text { Casamance } \\
\text { Estuary }\end{array}$ & Decrease & Increase & Decrease & & Increase \\
\hline \multirow{3}{*}{ Forests } & $\begin{array}{l}\text { Saloum } \\
\text { delta }\end{array}$ & $\begin{array}{l}\text { Both increase } \\
\text { and decrease }\end{array}$ & Decrease & & & \\
\hline & $\begin{array}{l}\text { Gambie } \\
\text { Estuary }\end{array}$ & $\begin{array}{l}\text { Both increase } \\
\text { and decrease }\end{array}$ & Increase & & & \\
\hline & $\begin{array}{l}\text { Casamance } \\
\text { Esuary }\end{array}$ & Decrease & & & & \\
\hline
\end{tabular}

Table 1 presents results related to observed changes that are observed within the MPAs. While the results in the Saloum Delta seem to agree, the other regions studied have many divergences among the different studies. For example, mangroves show more positive than negative evolutions according to the studies using satellite image, which seem to contradict the impressions of the managers. Only Carney's analysis supports their opinion. Even if the difference in time scale can be one of the reasons for these contradictions, details of each studies can be examined here.

Although studies mainly focus on mangrove areas, the study by Andrieu also covers those occupied by forests. This work notes that surface area losses are mainly present in the forests of MPAs in the Saloum Delta in Senegal (sites 2, 3 and 4, see Figure 4) and in the Rio Cacheu National Park in Guinea-Bissau (site 11 see Figure 4). Conversely, a positive evolution of the 
mangrove areas of all sites may be examined. This last observation contradicts the one of the managers, which generally expresses the opposite (except for the Palmarin (2) and Rio Cacheu (11) sites, where managers also indicated an increase in the forest area and mangrove).

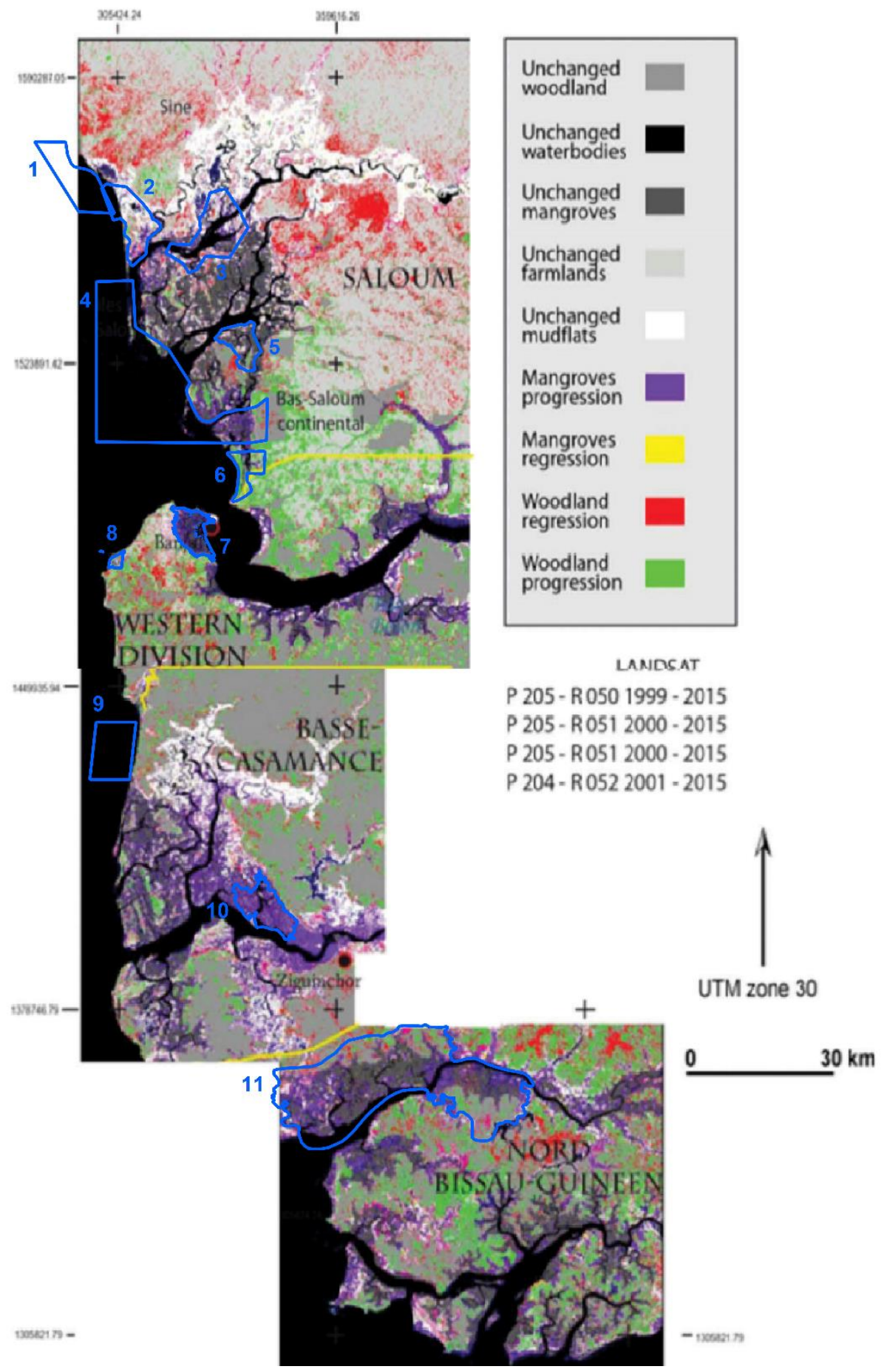

Figure 4: Satellite picture illustrating the evolution of habitats between 1999 and 2015 (Andrieu, 2018), with addition of the MPAs' contours studied in this work (orange). Sites: 1. Joal; 2. Palmarin; 3. Gandoul; 4. Sangomar; 5. Bamboung; 6. Niumi; 7. Tanbi; 8. Tanji; 9. Abene; 10. Kawawana; 11. Rio Cacheu 
Also analysing satellite images, Carney and Balla Dieye mapped changes in mangrove habitats. In the Saloum Delta (Balla Dieye et al., 2013), mangrove surface area increased within the boundaries of MPAs since the early 2000s (see Figure 5), as stated by the managers and Andrieu, especially along the canals (bolongs). In addition, mangrove surface losses have been identified as being very limited in his work.

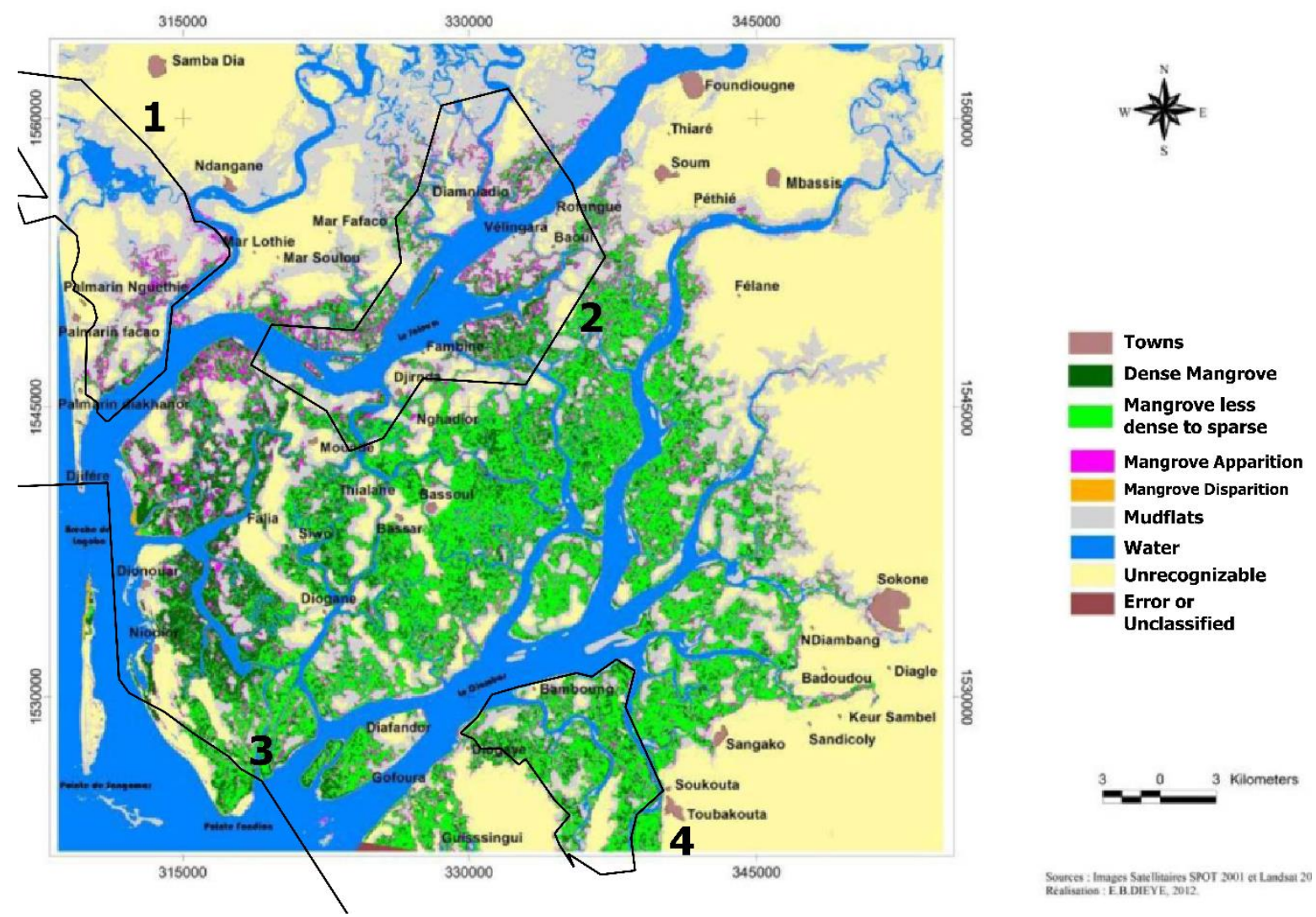

Figure 5: Evolution of mangroves between 2001 and 2010 according to satellite pictures (Balla Dieye et al., 2013) in Saloum Delta, with addition of the MPAs' contours studied in this work (dark orange). Sites: 1. Palmarin; 2. Gandoul; 3. Sangomar; 4. Bamboung

About Gambia River, Carney concluded that mangrove habitat in MPAs declines sharply. Over the period 1986-2010, mangrove habitat losses were more important along their edges and along the bolongs (sites 1, 2 and 3, see Figure 6). Managers' perception about mangroves changes in these MPAs matched the conclusions of Carney. However, the loss of mangrove habitats in the region is greater outside MPAs, especially upstream of major tributaries along the north shore (Carney, Gillespie and Rosomoff, 2014). 


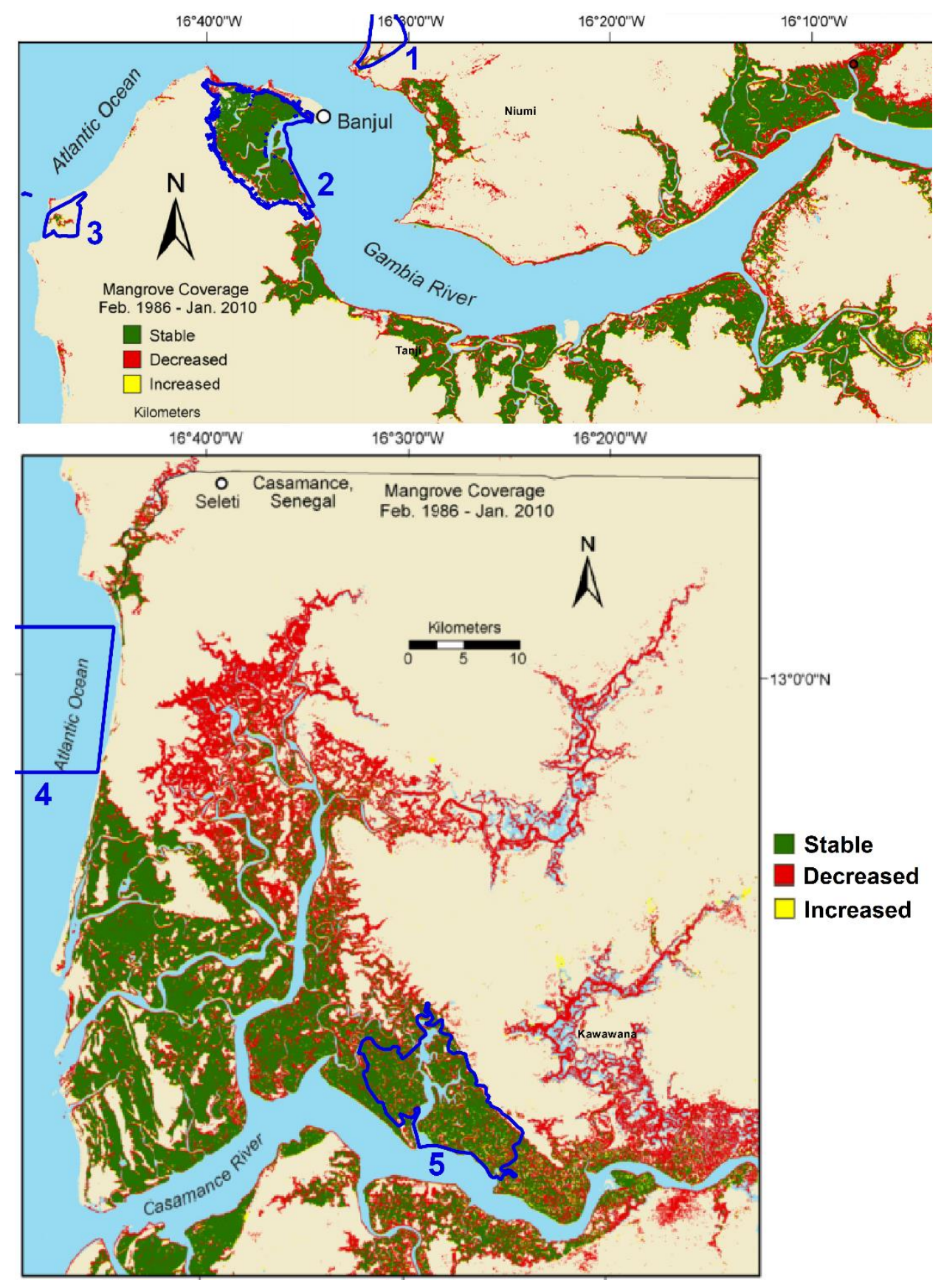

Figure 6: Evolution of mangroves between 1986 and 2010 according to satellite pictures (Carney, Gillespie and Rosomoff, 2014) along Gambia and Casamance rivers, with addition of the MPAs' contours studied in this work (blue). Sites: 1. Niumi; 2. Tanbi; 3. Tanji; 4. Abene; 5. Kawawana

The evolution of mangroves at the mouth of Casamance River in Senegal is more contrasting as some areas shrink while others increase. According to Carney, the Kawawana Protected Area in Senegal saw the surface area of its mangroves diminishing along the riverbeds and at its edges (site 5, see Figure 6); however, the manager did not specify an evolution of mangrove habitat within this site. The same phenomenon of habitat shrinking affects areas outside MPAs, particularly in the north, upstream of the main tributaries of Casamance. Conversely, Conchedda considers that the evolution of mangrove areas in Casamance between 1986 and 2006 is globally positive (see Figure 7), in line with Andrieu's analysis. 
The opinion of the managers interviewed in this zone, however, provided only little information on the evolution of the habitats during this period, since they only inform about the last few years.

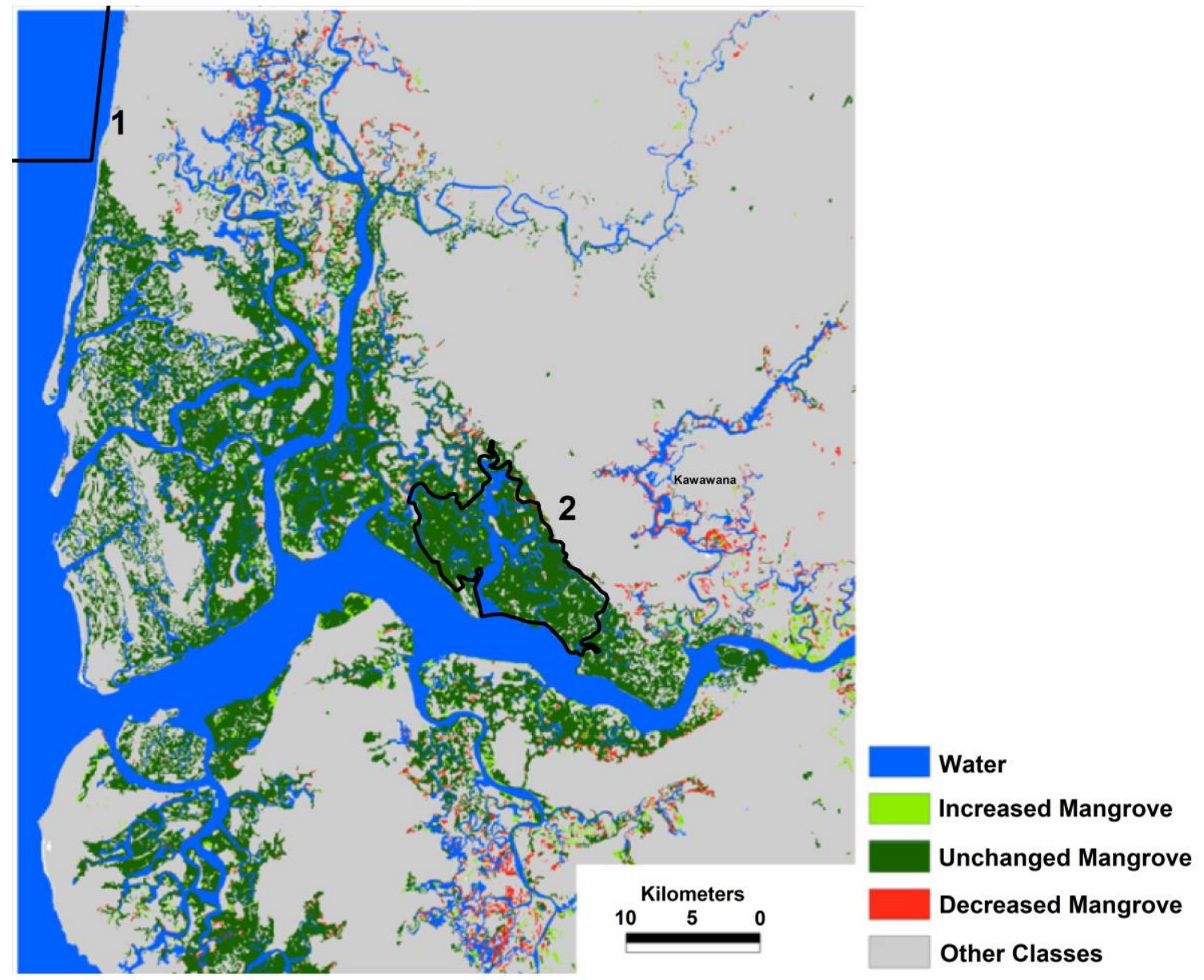

Figure 7: Evolution of mangroves between 1986 and 2006 according to satellite pictures (Conchedda, Durieux and Mayaux, 2008) in Casamance Estuary, with addition of the MPAs' contours studied in this work (yellow). Sites: 1. Abéné; 2. Kawawana

Regarding the beaches, an analysis of their surface would have little meaning, since it is more in their geographical position that the damage is manifested. The same observation applies to estuarine channels. In addition, there is currently no data on the retreat or advancement of the coastline that is generalized to all RAMPAO MPAs.

\section{Discussion}

Beaches, mangroves and mudflats are the natural habitats that suffer the greatest surface area losses in the studied MPAs because of increasing human pressure (Diop et al., 2018; Ndour et $a l ., 2018)$, climatic and natural causes of changes including erosion and sediments intake deficit (Faye, 2010b, 2010a; World Bank, 2019). The managers affirmed that erosion was the main threat occurring in the MPAs of the RAMPAO network (Failler et al., 2019). The consequences of rainfall deficits observed since the end of the 20th century (Niang et al., 
2010; Zwarts, 2014) resulted in the erosion of estuarine and coast shorelines due to the reduction of the intake of freshwater and sediment (Niang et al., 2010; Dia, 2012).

In the area of Saint Louis, alternatively, the loss of estuarine channel habitat was caused by the clogging of the mouth of the Senegal River which followed the voluntary gap in a sandy spit (Faye, 2010a; Balla Dieye et al., 2013). As the gap is gradually moving south, this affects the Langue de Barbarie National Park by drastically altering habitats and threatening the existence of Bird Island, an important nesting site. On the opposite, the creation of the Diawling National Park in Mauritania in the 1980s has subsequently given a new impulse to the natural habitats that were dried out since the erection of a dam complex in the $60 \mathrm{~s}$ and $70 \mathrm{~s}$ that are now used for regulating water flows in the MPA (El Habib Barry and Nuscia Taïbi, 2011). However, the main cause of the alteration of mangroves (both clearing up and decreasing of surface area) seems to be the cutting of wood for various activities (firewood, smoking of fish, oyster harvesting, constructions, extension of surface areas dedicated to agriculture) (Ndour, Dieng and Fall, 2012), especially in the most upstream mangrove areas. About the increase in forest surface areas, reforestation programs set back far enough from the coastline have allowed a regeneration of coastal forests and, to some extent, slowed erosion in some areas (Failler and Ba, 2017), when Mangrove planting programs do not appear to have been systematically successful (Cormier-Salem and Panfili, 2016). Seagrass beds, rocky bottoms and coral reefs, almost devoid of monitoring, indicate little change in progress. These habitats are not well understood (Renard and Touré, 2012; UNEP, 2016), as shown by the report of coral reefs in the MPA of Abene which seems unrealistic as they never have been reported in this place before, according to Reefbase.org. Considering that the MPA managers of the network report the evolution of the habitats based on visual impressions, it is challenging for them to assess large and submerged environment.

Subsequently, managers' perceptions were compared to different analyzes about mangroves and forest changes using satellite images, although these analyzes concerned entire areas instead of the only surface areas delineated by MPAs. As a result, affixing MPA contours to these maps can induce different trends than the regional evolution, since habitats losses in surface area seem greater outside MPAs. Nevertheless, an important point is that the analyzes carried out by satellite images differ from the impressions of the managers, with the exception of the one realized by Carney (2014). While satellite images globally show an improvement in mangrove and forests surface areas according to Andrieu (2018), Conchedda (2008) and Balla Dieye (2013) supported by an analysis from Temudo (2017) in Guinea Bissau, managers' opinions are more alarming. The main reason for the difference between manager perception and maps of habitats change is the use of different reference periods: those used by managers to make decisions are generally shorter than the one submitted to Satellite Imagery's examination. Managers are also able to express higher resolution in the habitat change by commenting on the quality of vegetation and wood cover, species density, etc. which mapping studies from satellite surveys often do not address, instead showing only changes in surface area. In addition, the lack of agreement, at the MPA level, of the results of Conchedda and Andrieu with those of Carney shows the lack of consistency between scientific researchers, which makes it more difficult to compare the opinions of managers with those of scientific 
work. While Conchedda and Andrieu noted a global improvement in the mangrove and forest surface area, Carney was much more pessimistic. The use of different methods can thus produce divergent results for wetlands because of the difficulties associated with a correct reading of the signal specific to each type of vegetation (Turmine, Binet and Failler, 2011; Perennou et al., 2018). For example, Andrieu made an analysis of the evolution of mangroves in the same place than Carney (here Tanbi MPA; see Figure 8) and during the same period, showing different results (Andrieu et al., 2019).

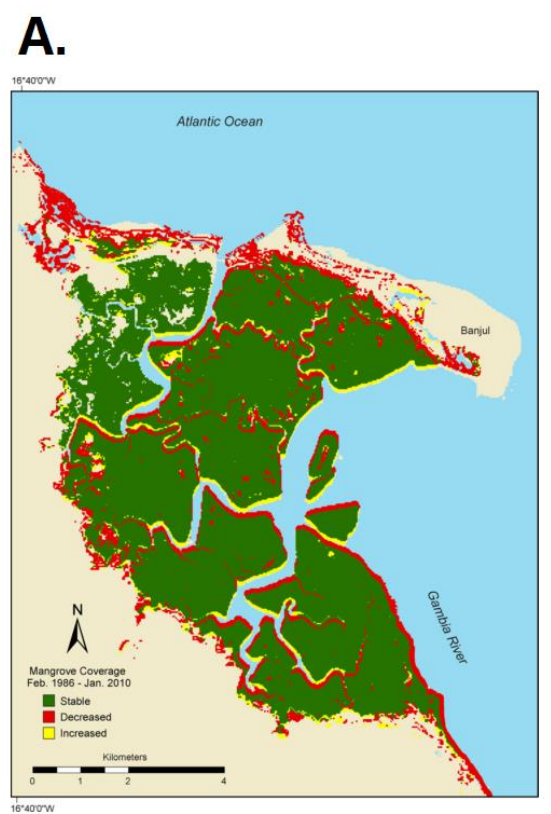

B.

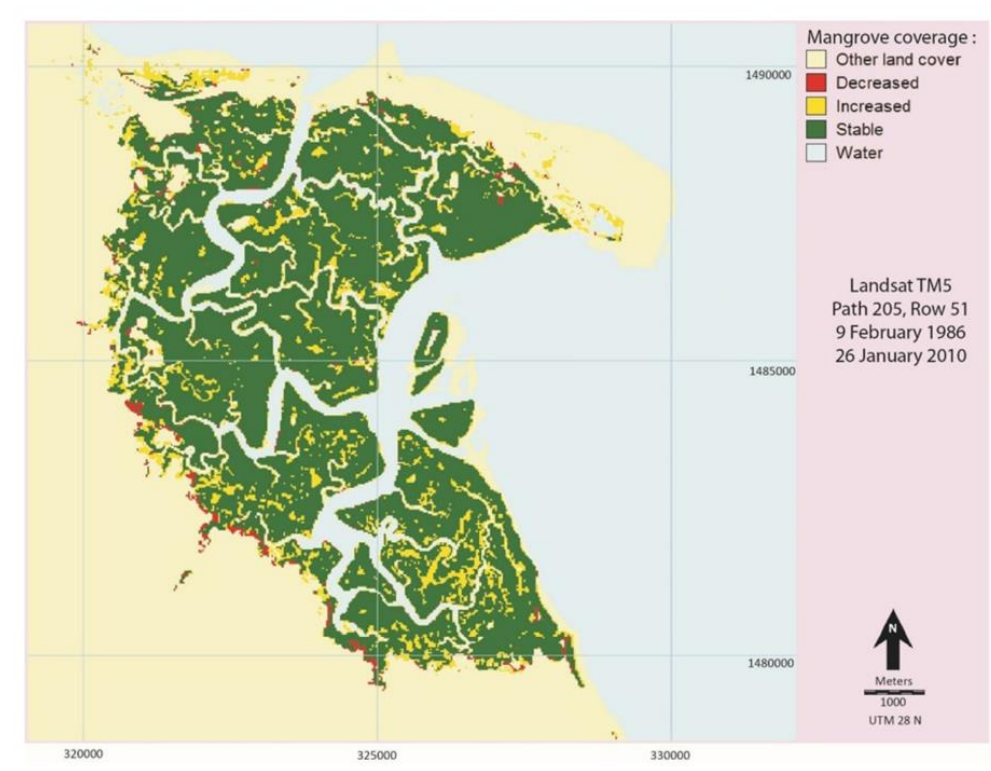

Figure 8: evolution of the mangrove surface area between 1986 and 2010 in Tanbi MPA according to A) Andrieu 2019; B) Carney 2014.

Note: Tanbi's manager reported a moderate decrease for the mangrove surface area during the present survey.

The gap between managers' perception and satellite imagery, however, is a consequence of the absence of a reference situation in terms of the surface area of ecosystems and their state of health, which makes any inter-temporal comparison impossible (Failler et al., 2015;

Trégarot, Failler and Maréchal, 2017). This also explains the lack of concordance between the observations of each other since each manager uses his own spatial and temporal referent, his own experience and his historicity within the MPA to elaborate his report.

The MPA managers of the network report the evolution of the habitats based on visual impressions, which can be considered as an "expert view" when the manager has been in post for many years, but in addition to be perfectible, this poses the problem of the absence of a distant reference situation for any newly appointed manager. Moreover, while they have limited financial, material and technical resources (Joyeux, Gale and Cobb, 2010; Staub, Diop and Tendeng, 2014; UNDP/Go-Wamer, 2017), their level of training is questionable as well as their ability to prospect the entire territory in their protected area. Instead, high-resolution satellite images, underwater cameras, logistical and human resources for field verification are more suitable methods for assessment. Furthermore, the absence of tangible data on the pressures induced by a population that is constantly expanding on natural resources (Gemenne 
et al., 2017) as well as on related industrialisation seems to influence managers and to make them develop a generally negative perception of the evolution of natural habitats. By projecting an imminent degradation of the habitats, they operate a temporal slip and consider that these are already undermined. The confusion between the real state and the potential risk is noticeable in the responses - particularly explanations provided regarding the reasons for environmental degradation. This appears to result from since managers confusing the explanatory cause (representing past and present time scales), risks and probable causes (representing the future). The effects of climate change are also feared as major risks. This is especially true as the events, little known apart from the rainfall deficit and its consequences, are expected to increase in the near future (UNEP-WCMC, 2016). Thus, an inaccurate measure of habitat change can lead to a disproportional management response.

Overestimating habitat loss leads to a more alarmist report and a disproportionate and inaccurate budget allocation for the habitat conservation. On the other hand, issuing an opinion that embellishes the actual situation to highlight the work done can be carried out in order to raise additional funds based on the successes achieved. In any case, the absence of a reference situation is detrimental: whether at the scale of MPAs or at the scale of the whole West African coastline, since any temporal and spatial comparison is impossible (without mentioning the change in reference points) (Pauly, 1995).

In the absence of data, perception surveys remain a good alternative to fill gaps in knowledge (Álvarez-Fernández et al., 2017). Besides its low price, this approach allows the emergence of local knowledge through a bottom-up process thanks to the participation of stakeholders (in this case, the local-based managers of MPAs). In addition, their perceptions inform about the socio-environmental context (Fatorić and Morén-Alegret, 2013). When confronted with satellite image analyzes, it helped to even better situate this context by identifying the differences in the results (lack of funds resulting in advocacy, lack of visibility, diffuse increase of threats on MPAs ...). In addition, the Rapid Appraisal Approaches whose perception surveys are part of have spread widely since the early 1990's in data-poor situations and when information must be provided promptly to help decision makers (Pido, 1995), especially in the field of coastal conservation (Haridhi et al., 2018). Such monitoring at the network level should take place on a regular basis, carried out jointly by regional administrations and other stakeholders.

However, lack of data on land use changes (both emerged and submerged) is problematic in the MPAs of the network, since only a few punctual representations of the emerged habitats have been carried out. The need for reference data on surface areas at a specific moment is critical to analyze the evolution of habitats and thus to guide public policies considering that MPAs are among the essential elements of the environmental strategies of the countries in the study area and their positive impact has already been demonstrated (Triplet, 2009; El Habib Barry and Nuscia Taïbi, 2011; Laë et al., 2015; Weigel et al., 2018). For example, it is likely that the increase in mangrove habitat areas in Saloum Delta occurred at the same time as the creation of MPAs in 2001. Prior to MPAs creation, there was a significant decline in mangrove habitats (Zwarts, 2014), due to agricultural practices, particularly rice cultivation, and or simply consecutive to a lack of rain with the emergence of salt flats (Balla Dieye et al., 
2013). The increase in mangrove habitats has been consistent within MPAs, notably through actions of reforestation and irrigation, and their growth has extended to outside MPAs boundaries. Unfortunately, no work has yet been done in West Africa to record the sustainability of mangrove reforestation. Finally, the place of geographic information related to MPAs must be increased among conservation stakeholders in RAMPAO area (administrations, NGOs and international cooperation in particular) as they are included in the international conventions signed by these countries: MPAs are thus the subject of Articles 14 and 15 of the Sustainable Development Goals, Aichi Target 11 (Convention on Biological Diversity) and Article 11 of the Abidjan Convention.

\section{Conclusion}

According to the managers of RAMPAO MPAs, the habitats currently most affected by global changes (natural and anthropogenic) are beaches, mudflats and mangroves. Managers have, for many years, observed a loss in beach habitats due to an acceleration of erosion caused by increasing frequency of storms and the amplitude of waves (Faye, 2010b; Failler $e t$ al., 2019). For mudflats, managers consider that the environment suffers from water stress due to a rainfall deficit, which turn them to dryer ecosystems (Balla Dieye et al., 2013; Toure et $a l ., 2016)$, and a general rise in temperatures in West Africa (IPBES, 2018). The main way for the managers to monitor habitats is by visual observation. No rigorous monitoring work or scientific analysis is currently available to draw a parallel statement to that of managers. For mangroves, the scientific literature enumerates the same threats as those mentioned above with, in addition, an anthropic pressure resulting from the cutting of wood for the smoking of the fish, the picking of the oysters, for habitat and tool construction and the cooking (Sakho et al., 2011). The analyses using satellite images are not always of a sufficiently precise resolution, given the modest size of most MPAs to validate the observations made by MPA managers. In addition to not always agreeing with the impressions of MPA managers, these studies sometimes contradict each other and there is no overall consensus.

Forests are the only habitat to have, according to the managers of the MPAs, a relatively positive evolution. However, satellite imagery show that mangroves are also in expansion. It can be explained by a certain awareness of MPA populations and by the implementation of significant reforestation projects involving them (PRCM et al., 2015; Cormier-Salem, 2017). The perception of the evolution of this environment relies on a regular visual observation. The ability for MPA managers to accurately assess habitats is less precise the more aquatic the habitat becomes. The lack of a reference situation is another handicap to establish a wellfounded observation (Renard and Touré, 2012).

The absence of monitoring of seagrass beds, coral reefs and rocky bottoms shows a generalized poor information on the state of the marine environment. However, the knowledge of seagrasses in West Africa will likely be improved by the ResilienSEA Project and the seagrasses survey which has just been done at the National Park of Banc d'Arguin (Trégarot et al., 2018). The results of these works should lay the foundations for more systematic monitoring of seagrasses along the West African coast, and contribute towards a better understanding of changes in the marine environment by managers. 
The information provided by MPA managers using visual observations surveys can be of suitable quality and can help partially to fill the gaps related to the lack of scientific monitoring (Álvarez-Fernández et al., 2017). Managers also are a source of valuable in situ knowledge, which is essential for the development of regional knowledge that can be used for management purposes (Fatorić and Morén-Alegret, 2013; Rodríguez-Rodríguez and Martínez-Vega, 2016). However, visual observations can be limited, especially when it is related to marine environment. Thus, the validity of information of these habitats provided by managers can decline. Indeed, this needs to be considered during work on the establishment of inventory, baseline situation, study of changes, changes in habitats, etc. especially with socalled Rapid Appraisal Approaches. Particular attention must be paid to the nature and the basis of the assessment made by the manager.

\section{Annex}

Questionnaire (in French and/or English) sent to MPAs managers.

\section{Acknowledgements}

The authors thank all MPA managers, the Regional Partnership for the Conservation of the Coastal and Marine Zone in West Africa (PRCM) as well as all persons in the administrations who kindly provided the requested information.

\section{Bibliography}

Alban, F. et al. (2011) 'Evaluation pluridisciplinaire de l'efficacité d'une AMP emblématique: le cas du bolong de Bamboung au Sénégal', in Contribution des aires marines protégées à la gestion éco systémique des milieux et de leurs usages : quelle stratégie scientifique? Paris, France, p. 13.

Alvarez-Berastegui, D. et al. (2014) 'Multidisciplinary rapid assessment of coastal areas as a tool for the design and management of marine protected areas', Journal for Nature Conservation, 22(1), pp. 1-14. doi: 10.1016/j.jnc.2013.07.003.

Álvarez-Fernández, I. et al. (2017) 'The management performance of marine protected areas in the North-east Atlantic Ocean', Marine Policy. Elsevier, 76, pp. 159-168. doi: 10.1016/j.marpol.2016.11.031.

Andrieu, J. (2018) 'Land cover changes on the West-African coastline from the Saloum Delta (Senegal) to Rio Geba (Guinea-Bissau) between 1979 and 2015', European Journal of Remote Sensing. Taylor \& Francis, 51(1), pp. 314-325. doi: 10.1080/22797254.2018.1432295.

Andrieu, J. et al. (2019) 'Correctly assessing forest change in a priority West African mangrove ecosystem: 1986-2010 An answer to Carney et al. (2014) paper "Assessing forest change in a priority West African mangrove ecosystem: 1986-2010", Remote Sensing Applications: Society and Environment. Elsevier B.V., 13, pp. 337-347. doi: 10.1016/j.rsase.2018.12.001.

Balla Dieye, E. H. et al. (2013) 'Dynamique de la mangrove de l'estuaire du Saloum (Sénégal) entre 1972 et 2010', CyberGeo: European Journal of Geography. doi: $10.4000 /$ cybergeo. 25671 . 
Carney, J., Gillespie, T. W. and Rosomoff, R. (2014) 'Assessing forest change in a priority West African mangrove ecosystem: 1986-2010’, Geoforum. Elsevier Ltd, 53, pp. 126-135. doi: 10.1016/j.geoforum.2014.02.013.

Ceesay, A. et al. (2017) 'Mangrove Vegetation Dynamics of the Tanbi Wetland National Park in The Gambia', Environment and Ecology Research, 5(2), pp. 145-160. doi: 10.13189/eer.2017.050209.

Conchedda, G., Durieux, L. and Mayaux, P. (2008) 'An object-based method for mapping and change analysis in mangrove ecosystems', ISPRS Journal of Photogrammetry and Remote Sensing, 63(5), pp. 578-589. doi: 10.1016/j.isprsjprs.2008.04.002.

Cormier-Salem, M.-C., Dieye, B. and Sane, T. (2016) 'Légitimité des politiques de reboisements de mangrove en Casamance', in L'Harmattan (ed.) Eaux et sociétés face au changement climatique dans le bassin de la Casamance. Paris, France, pp. 189-210.

Cormier-Salem, M. C. (2017) 'Let the women harvest the mangrove. Carbon Policy, and Environmental Injustice', Sustainability, 9(1485), pp. 1-18. doi: 10.3390/su9081485.

Cormier-Salem, M. C. and Panfili, J. (2016) 'Mangrove reforestation: greening or grabbing coastal zones and deltas? Case studies in Senegal', African Journal of Aquatic Science, 41(1), pp. 89-98. doi: 10.2989/16085914.2016.1146122.

Dia, I. (2012) Vulnerability Assessment of Central Coast Senegal (Saloum) and The Gambia Marine Coast and Estuary to Climate Change Induced Effects. Available at: http://www.crc.uri.edu.

Diop, A. et al. (2018) 'Dynamique d'occupation du sol des zones humides urbanisées de Dakar (Sénégal) de 1942 à 2014', VertigO, 18(1).

Diop, S. and Scheren, P. A. (2016) 'Sustainable oceans and coasts: Lessons learnt from Eastern and Western Africa', Estuarine, Coastal and Shelf Science. Elsevier Ltd, 183, pp. 327-339. doi: 10.1016/j.ecss.2016.03.032.

Duncan, C. et al. (2018) 'Satellite remote sensing to monitor mangrove forest resilience and resistance to sea level rise', Methods in Ecology and Evolution, 9(8), pp. 1837-1852. doi: 10.1111/2041-210X.12923.

Failler, P. et al. (2015) 'Valuation of marine and coastal ecosystem services as a tool for conservation: The case of Martinique in the Caribbean', Ecosystem Services. Elsevier, 11, pp. 67-75. doi: 10.1016/j.ecoser.2014.10.011.

Failler, P. et al. (2019) 'Menaces sur les aires marines protégées en Afrique de l'Ouest: de la pêche non contrôlée aux changements climatiques', Mondes en développement, 187(3), pp. 133-152. doi: 10.3917/med.187.0133.

Failler, P. et al. (2020) 'Evaluating the official achievement of Aichi Target 11 for West African countries: A twofold challenge of accuracy and catching-up', Science of The Total Environment. Elsevier B.V., 698. doi: 10.1016/j.scitotenv.2019.134284.

Failler, P. and Ba, T. (2017) Evaluation Finale du projet Gestion Intégrée des Zones Côtières - Sénégal Evaluation Finale du projet Gestion Intégrée des Zones Côtières - Sénégal Requête $n$ ○ 2016/379204-1. Bruxelles. 
Failler, P., Sadio, O. and Touron-Gardic, G. (2018) État de référence des Aires Marines Protégées du RAMPAO. Dakar, Sénégal.

Fatorić, S. and Morén-Alegret, R. (2013) 'Integrating local knowledge and perception for assessing vulnerability to climate change in economically dynamic coastal areas: The case of natural protected area Aiguamolls de 1'Empordà, Spain', Ocean and Coastal Management, 85, pp. 90-102. doi: 10.1016/j.ocecoaman.2013.09.010.

Faye, I. B. N. (2010a) Dynamique du trait de côte sur les littoraux sableux de la Mauritanie à la Guinée-Bissau (Afrique de l'Ouest) : Approches régionale et locale par photo-interprétation, traitement d'images et analyse de cartes anciennes. Matériel Supplémentaire. Université de Bretagne occidentale.

Faye, I. B. N. (2010b) Dynamique du trait de côte sur les littoraux sableux de la Mauritanie à la Guinée-Bissau (Afrique de l'Ouest) : Approches régionale et locale par photo-interprétation, traitement d'images et analyse de cartes anciennes. Volume 1. Université de Bretagne Occidentale, France.

Gemenne, F. et al. (2017) 'Climate change, natural disasters and population displacements in West Africa ', Geo-Eco-Trop, 41(3), pp. 317-337. Available at: https://www.scopus.com/inward/record.uri?eid=2-s2.0-

$85042259973 \&$ partnerID=40\&md5=ed52aa9b229e67a8b3a3adbd6fa91117.

Gourmelon, F. et al. (2006) 'Contraintes d'utilisation des Technologies de l'Information Géographique pour la GIZC en Afrique’, VertigO, 7(3).

El Habib Barry, M. and Nuscia Taïbi, A. (2011) 'Du Parc National du Diawling à la Réserve de Biosphère Transfrontalière : jeux d'échelles à l'épreuve du développement durable dans le bas delta du fleuve Sénégal Du Parc National du Diawling à la Réserve de Biosphère Transfrontalière : jeux d'échelles à', in Bordeaux, P. U. de (ed.) Natures tropicales : enjeux actuels et perspectives. Bordeaux, France, pp. 147-156. Available at: https://hal.archivesouvertes.fr/hal-00936306.

Haridhi, H. A. et al. (2018) 'Application of Rapid Appraisals of Fisheries Management System (RAFMS) to identify the seasonal variation of fishing ground locations and its corresponding fish species availability at Aceh waters, Indonesia', Ocean and Coastal Management. Elsevier, 154, pp. 46-54. doi: 10.1016/j.ocecoaman.2017.12.030.

He, C. et al. (2014) 'Urban expansion dynamics and natural habitat loss in China: A multiscale landscape perspective', Global Change Biology, 20(9), pp. 2886-2902. doi: 10.1111/gcb.12553.

IPBES (2018) THE REGIONAL ASSESSMENT REPORT ON BIODIVERSITY AND ECOSYSTEM SERVICES FOR AFRICA II SUMMARY FOR POLICYMAKERS OF THE IPBES REGIONAL ASSESSMENT REPORT ON BIODIVERSITY AND ECOSYSTEM SERVICES FOR AFRICA Disclaimer on maps Photo credits Technical Support Graph. Available at: www.ipbes.net.

Joyeux, C., Gale, J. and Cobb, S. (2010) Analyse des mécanismes de financement des aires marines protégées d'Afrique de l'ouest - Tome 1: Analyse du contexte sous-régional pour le financement durable des AMP d'Afrique de l'Ouest. Dakar, Sénégal.

Laë, R. et al. (2015) 'Bénéfices attendus et réels des AMP pour la restauration et la gestion des 
ressources marines en Afrique de l'ouest', in IRD Editions (ed.) Aires marines protégées ouestafricaines, pp. 117-141.

Ndour, A. et al. (2018) 'Management strategies for coastal erosion problems in west Africa: Analysis, issues, and constraints drawn from the examples of Senegal and Benin', Ocean and Coastal Management, 156, pp. 92-106. doi: 10.1016/j.ocecoaman.2017.09.001.

Ndour, N., Dieng, S. D. and Fall, M. (2012) 'Rôles des mangroves, modes et perspectives de gestion au Delta du Saloum (Sénégal)', VertigO, 11(3). doi: 10.4000/vertigo.11515.

Niang, I. et al. (2010) 'Impacts of climate change on the Senegalese coastal zones: Examples of the Cap Vert peninsula and Saloum estuary', Global and Planetary Change. Elsevier B.V., 72(4), pp. 294-301. doi: 10.1016/j.gloplacha.2010.01.005.

Pauly, D. (1995) 'Anecdotes and the shifting baseline syndrome of fisheries', Trends in Ecology and Evolution, 10(10), p. 430.

Perennou, C. et al. (2018) 'Mapping Mediterranean Wetlands With Remote Sensing: A GoodLooking Map Is Not Always a Good Map', Advances in Ecological Research. Academic Press, 58, pp. 243-277. doi: 10.1016/BS.AECR.2017.12.002.

Pido, M. D. (1995) 'The application of Rapid Rural Appraisal techniques in coastal resources planning: experience in Malampaya Sound, Philippines', Ocean and Coastal Management, 26(1), pp. 57-72. doi: 10.1016/0964-5691(95)00011-P.

PRCM et al. (2015) Développement d'un programme régional sur la conservation et la gestion des écosystèmes de mangroves en Afrique de l'Ouest. Dakar, Sénégal.

Renard, Y. and Touré, O. (2012) Itinéraires de création d'Aires Marines Protégées en Afrique de l'Ouest - Expériences et leçon apprises. Dakar, Sénégal: FIBA/RAMPAO/PRCM.

Rodríguez-Rodríguez, D. and Martínez-Vega, J. (2016) 'What should be evaluated from a manager's perspective? Developing a salient protected area effectiveness evaluation system for managers and scientists in Spain', Ecological Indicators. Elsevier Ltd, 64, pp. 289-296. doi: 10.1016/j.ecolind.2016.01.011.

Sakho, I. et al. (2011) 'The influence of natural and anthropogenic factors on mangrove dynamics over 60 years: The Somone Estuary, Senegal', Estuarine, Coastal and Shelf Science, 94(1), pp. 93-101. doi: 10.1016/j.ecss.2011.05.032.

Staub, F., Diop, D. D.- and Tendeng, P. (2014) RAMPAO 2014 : Analyse de compétences et lacunes des acteurs du Réseau régional d'aires marines protégées en Afrique de l'Ouest et recommandations. Dakar, Sénégal.

Temudo, M. P. and Cabral, A. I. (2017) 'The Social Dynamics of Mangrove Forests in GuineaBissau, West Africa', Human Ecology. Human Ecology, 45(3), pp. 307-320. doi: 10.1007/s10745-017-9907-4.

Toure, M. A. et al. (2016) 'Using of Landsat Images for Land Use Changes Detection in the Ecosystem_A Case Study of the Senegal River Delta', International Journal of Environment, Agriculture and Biotechnology, 1(2). doi: 10.22161/ijeab/1.2.15.

Trégarot, E. et al. (2018) Évaluation des services écosystémiques du Banc d'Arguin, Mauritanie: Rapport Final. 
Trégarot, E., Failler, P. and Maréchal, J. P. (2017) 'Evaluation of coastal and marine ecosystem services of Mayotte: Indirect use values of coral reefs and associated ecosystems', International Journal of Biodiversity Science, Ecosystem Services and Management. Taylor \& Francis, 13(3), pp. 19-34. doi: 10.1080/21513732.2017.1407361.

Triplet, P. (2009) Manuel de gestion des aires protégées d'Afrique francophone, Awely. Edited by Fondation Awely. doi: <hal-00669157>.

Turmine, V., Binet, T. and Failler, P. (2011) 'L'usage de la télédétection pour l'évaluation économique des écosystèmes marins: application à l'aire marine protégée de Tristão en Guinée', VertigO, 11(3). doi: 10.4000/vertigo.12234.

UNDP/Go-Wamer (2017) Étude sur l'évaluation de l'efficacité de gestion des aires marines protégées dans la sous-région Go-Wamer. doi: 10.3917/presa.181.0441.

UNEP-WCMC (2016) Impacts du changement climatique sur la biodiversité et les aires protégées en Afrique de l'Ouest, Résumé des résultats du projet PARCC, Aires protégées résilientes au changement climatique en Afrique de l'Ouest. Cambridge, UK. Available at: http://parcc.protectedplanet.net/system/comfy/cms/files/files/000/000/164/original/PARCC_F R_WEB.pdf.

UNEP (2016) Blue Carbon Financing of Mangrove Conservation in the Abidjan Convention Region - A Feasibility Study. Nairobi, Abidjan and Arendal.

United Nations, D. of economic and social affairs (2017) World Population Prospects: The 2017 Revision.

Vasconcelos, M. J. P. et al. (2002) 'Land cover change in two protected areas of Guinea-Bissau (1956-1998)', Applied Geography, 22(2), pp. 139-156. doi: 10.1016/S0143-6228(02)00005-X.

Weigel, J. Y. et al. (2018) 'Impact assessment of a marine and coastal protected area on fishing households through a counterfactual approach. A Senegalese case study (West Africa)', Ocean and Coastal Management. Elsevier, 155, pp. 113-125. doi: 10.1016/j.ocecoaman.2018.02.009.

World Bank (2019) The Cost of Coastal Zone Degradation in West Africa. doi: 10.1596/31428.

Zwarts, L. (2014) Mangrove dynamics in West Africa, A\&W-report 2029. Gland, Switzerland. 